\title{
Horizon scanning: survey and research priorities for cultural, historical, and paleobiological resources of Santa Cruz Island, California
}

\author{
Torben C. Rick ${ }^{1, *}$, Todd J. Braje 2 , Jon M. ErLandson ${ }^{3}$, Kristina M. GilL 3,4 , \\ LaUra Kirn 5 , and LYNn MCLaren-Dewey 6 \\ ${ }^{1}$ Department of Anthropology, National Museum of Natural History, Smithsonian Institution, \\ MRC 112, Washington, DC 20013-7012 \\ ${ }^{2}$ Department of Anthropology, San Diego State University, San Diego, CA 92182-6040 \\ ${ }^{3}$ Museum of Natural and Cultural History, University of Oregon, Eugene, OR 97403 \\ ${ }^{4}$ Santa Barbara Botanical Garden, 1212 Mission Canyon Rd., Santa Barbara, CA 93105 \\ ${ }^{5}$ Channel Islands National Park, 1901 Spinnaker Dr., Ventura, CA 93001 \\ ${ }^{6}$ University of California Natural Reserve System, University of California, Santa Barbara, CA 93106-6150
}

\begin{abstract}
Santa Cruz Island contains a remarkable array of cultural and biological resources and a rich tradition of research across the social and biological sciences and humanities. Given dramatic changes in climate forecast in the coming decades of the Anthropocene, however, many questions remain about the sustainability and future of island ecosystems and cultural resources. Here, we focus on a new interdisciplinary initiative, Island Rediscovery (IR), that was the subject of 2 recent workshops. Drawing on a variety of disciplines and approaches, IR seeks to utilize research on Santa Cruz Island's past and present to help better prepare for the future and plan for forecast change, an approach we call horizon scanning. Our focus is on archaeology, history, and paleobiology, 3 disciplines that offer deep historical perspectives critical to understanding modern ecosystems and preparing for future variability. We outline the potential of deep historical research, offer core questions that can guide future work, and document the need for a large synthetic database and digitization effort. By integrating the historical and biological sciences, the historical ecological approach of IR offers a new framework for managing the resources of the California Islands by providing baselines and context for management, documenting the range of ecological variability through deep time, and helping establish desired future conditions.
\end{abstract}

Resumen.-La isla Santa Cruz cuenta con una notable variedad de recursos culturales y biológicos y con una rica tradición en investigación en el campo de las ciencias sociales y biológicas y de las humanidades. Sin embrago, debido a los dramáticos cambios en el pronóstico climático de las próximas décadas del Antropoceno, quedan muchas preguntas por resolver acerca de la sustentabilidad y del futuro de los ecosistemas insulares, y de los recursos culturales. Aquí, nos centramos en una nueva iniciativa interdisciplinaria llamada Redescubrimiento Insular (IR, por sus siglas en inglés), que fue el tema principal de dos talleres recientes. Basándose en una variedad de disciplinas y de enfoques, IR se enfoca en la investigación del pasado y del presente de la Isla Santa Cruz para ayudar a prepararse mejor para el futuro y para el cambio en en las predicciones, un enfoque al que llamamos escaneo del futuro. Nuestro enfoque se centra en la arqueología, la historia y la paleobiología, tres disciplinas que ofrecen profundas perspectivas históricas, fundamentales para la comprensión de los ecosistemas modernos y para proyectarnos la variabilidad futura. Describimos el potencial de una investigación histórica profunda, ofrecemos preguntas básicas que pueden ayudar a orientar el trabajo futuro y documentamos la necesidad de una gran base de datos sintética y de un esfuerzo de digitalización. Al integrar las ciencias históricas y biológicas, el enfoque ecológico histórico de IR ofrece un nuevo marco para administrar los recursos de las Islas California, proporcionando las bases de referencia y el contexto para su gestión, documentando la gama de variabilidad ecológica a través del tiempo y ayudando a establecer las condiciones futuras deseadas.

When strategizing about how best to manage the organisms, ecosystems, and cultural resources of Santa Cruz Island, researchers and managers are confronted with a rapidly changing world and a growing set of challenges. Most researchers probably agree that to best manage Santa Cruz Island's unique resources, they need to be armed with the

*Corresponding author: rickt@si.edu 
best possible data and information about the current state of island ecosystems and the variables that contribute to ecosystem stability and resilience. Managers also need to consider the future and scan the horizon for how climate change, invasive species, and other anthropogenic and natural factors might affect island organisms, ecosystems, and cultural resources. To enhance management strategies, we need information about the past, especially baseline conditions and information on the range of ecological variability through time, which can document past conditions and provide potential targets for restoration (Pauly 1995, Jackson et al. 2001, Rick et al. 2014a).

The integration of the past, present, and future of Santa Cruz Island ecosystems is at the core of the Island Rediscovery (IR) initiative (Morrison et al. 2018). IR represents a bold way of thinking about the management, sustainability, and restoration of Santa Cruz Island, the California Islands at large, and other areas around the world. It integrates biology, geology, social sciences, and humanities within a comprehensive framework for addressing the many challenges that face the Channel Islands in the Anthropocene or Age of Humans. Given the complexities of integrating these distinct disciplines and approaches, which draw on different data sets with unique temporal and spatial resolution, questions remain about how best to move forward with the IR initiative.

During two 2016 workshops, the first at the Santa Barbara Museum of Natural History and the latter at the 9th California Islands Symposium, we worked to advance the historical ecological framework of IR by planning for the integration of data on the past, present, and future of Santa Cruz Island. Specifically, we focused on 3 questions we believe are crucial for future research on Santa Cruz and other islands around the world: (1) How can researchers better document past conditions? (2) How can researchers better document present conditions? And (3) how can researchers better capitalize on historically and contemporarily collected materials to make the most informed conservation decisions? Our "cultural" group was one of 4 clusters, the others being terrestrial fauna, terrestrial flora, and marine ecosystems. In far-reaching conversations that included much more than the cultural resources of Santa Cruz Island, our group explored paleobiology, archaeology, history, ecology, and indigenous knowledge. Here, we evaluate the core IR research questions and demonstrate the value of cultural and other deep historical data for understanding the past, present, and future of Santa Cruz Island ecosystems and conservation priorities. Along the way we touch on the utility of emerging technologies, the value of deep historical data, the significance of museum collections, the need for a variety of "big data" sets, the importance of working with Chumash and Tongva partners, and the applicability of this approach for other islands of the Pacific coast and around the world.

\section{Management Area And RESOURCES OF INTEREST}

Santa Cruz Island is $249 \mathrm{~km}^{2}$ and the largest of the 8 California Channel Islands. Santa Cruz Island is located roughly $30 \mathrm{~km}$ offshore, between Anacapa Island to the east and Santa Rosa Island to the west. It has the greatest variety of terrestrial resources on the Channel Islands, including some 480 native plant species and 4 terrestrial mammals (not including bats and humans), the largest of which are the island fox (Urocyon littoralis) and the island spotted skunk (Spilogale gracilis amphiala; Junak et al. 1995, Schoenherr et al. 1999). The island contains northern and southern ranges of mountains separated by a large Central Valley, with numerous perennial streams and springs that provide some of the greatest freshwater availability on the Channel Islands (Jazwa and Perry 2013). Still, the island has a dry Mediterranean climate, with about 15 inches $(381 \mathrm{~mm})$ of rain per year supplemented by fog drip in many areas (Fischer et al. 2009). Santa Cruz Island, like all of California, was in a major multiyear drought until 2017 due to decreased rainfall and diminishing precipitation from fog drip (Witiw and LaDochy 2008, LaDochy and Witiw 2012).

Santa Cruz Island's large size, diverse range of terrestrial and marine organisms and ecosystems, proximity to the mainland, and central location to the other Northern Channel Islands have long made it an attractive place for human settlement (Arnold 2001, Glassow et al. 2008, Gusick 2012). The oldest radiocarbon-dated archaeological sites are approximately 10,000 years old (Erlandson et al. 
2015a, 2016a), but chipped stone crescents recovered from a few island sites hint at an occupation spanning some 13,000 to 12,000 years ago like the other Northern Channel Islands (Erlandson et al. 2011). Native Americans occupied the island throughout the Holocene and established massive Late Holocene villages scattered around the island. These settlements include some 11 villages occupied in historical times (Arnold 1990, Johnson and McLendon 1999, Kennett 2005), before the Island Chumash were forcibly moved or compelled to abandon their island homes to Spanish mainland missions or pueblos by about AD 1822. Chinese abalone fishers occupied the island starting in the mid-19th century (Braje 2016) and the Ranching Period (post AD 1850) ushered in a dramatic transformation of island ecosystems in the mid- to late19th century (Junak et al. 1995, Rick et al. 2014a, McEachern et al. 2016).

Because of its relative accessibility and numerous harbors, Santa Cruz is one of the most frequently visited Channel Islands by the public, including nearly 60,000 people visiting the island each year via the boats of Island Packers Cruises (Ventura, CA) alone. Most visitors arrive to the island at Scorpion Anchorage or Prisoners Harbor. These are 2 locations that had large Chumash settlements, Swaxil at Scorpion and Xaxas at Prisoners, a testament to the locations as persistent places where people lived for millennia. Today, the island is jointly owned and managed by The Nature Conservancy (TNC) and the National Park Service (NPS), the latter managing most of the area east of Prisoners Harbor and the former managing the western three-quarters of the island. TNC and NPS consult and cooperate on island management issues. The island is also part of the University of California Natural Reserve System, with a research field station located in the Central Valley. A wide variety of researchers, restoration ecologists, conservationists, students, and others visit and work on the island annually.

\section{Documentation of the Past}

One of the cultural group's strengths is the documentation of the past, given our focus on archaeology, history, and paleobiology. This strength is well aligned with one of the 3 guiding questions from the workshop: How do we better document the past? Our temporal focus ranges from the formation of the California Islands some 60 million years ago to the arrival of humans $\geq 13,000$ years ago through to the historical and modern periods. Consequently, we slightly shifted our question about the past as follows: What do we know about the deep history of Santa Cruz Island? Despite a long tradition of deep historical research on the Channel Islands (and Santa Cruz Island specifically), our data remain incomplete and patchy, and questions linger about how best to document and understand Santa Cruz Island's past.

Research on the archaeology, history, geology, and paleobiology of Santa Cruz Island is relatively well published. For archaeology, early contributions were made by Rogers (1929), Olson (1930), and Hoover (1971). More recent contributions include work by Arnold (1987, 1991, 2001), Colten (1993, 2001), Colten and Arnold (1998), Gusick et al. (2016), Martin and Popper (2001), Noah (2004), Thakar (2012), and others. These works provide data from about 1500 years ago to the Historic Period from a series of ethnographically documented or other Late Holocene Chumash villages and they also provide quantified faunal data that can help reconstruct human interactions with past animal populations (see also Jew et al. 2015). Recent work at other sites by Arnold and Martin (2014), Gill (2013, 2014, 2015, 2016), Gill and Hoppa (2016), Hoppa (2014), and Thakar (2016) provide important insights into Chumash ethnobotany on Santa Cruz Island, which has great potential for helping understand past island plant communities and the influence of ancient peoples on island ecosystems. Further back in time, data from Early and Middle Holocene sites are also available, including Glassow's work (Glassow 1993a, 1993b, 2013, 2015, Glassow et al. 2008) at a variety of red abalone middens and the Punta Arena site (CA-SCRI-109) that provides comprehensive faunal data for these earlier time periods. Similarly, recent work by Gusick (2012, 2013) and Erlandson et al. (2015a, 2016a) provide data from Early Holocene sites and some of the oldest archaeological sites yet documented on the island. Perry's research (Perry 2003, 2004, 2005, Perry and Hoppa 2012), primarily on eastern Santa Cruz Island, provides insights into human settlement and land use strategies on the island, as well as 
human subsistence strategies. Building on this work, a series of papers focused on understanding the nature of human settlement systems on the interior of Santa Cruz Island (Perry and Glassow 2015, 2016, Erlandson 2016). Braje's work (Braje 2016) on the Chinese abalone fishery synthesizes historical archaeological data for the largely undocumented period after Chumash removal from the island and prior to establishment of modern ecological studies and resource management infrastructure.

Work on historical documents has also been increasing and has a long research tradition that helps paint a picture of the historical occupations of the Channel Islands from the mid-1800s to the present. Livingston's research (Livingston 2006, 2016) chronicles successive ranching occupations of the island, including sheep and other livestock operations, orchards, eucalyptus and olive groves, and vineyards. Along with fish shacks, U.S. Navy use, a penal colony, and movie sets, these and other historical uses transformed Santa Cruz Island's native ecosystems into ones dominated by introduced grasses and livestock (Livingston 2006). Plant and animal introductions or invasions-as well as eradication efforts-have been a major component of TNC, NPS, and U.S. Navy conservation and management efforts on the Channel Islands (Rick et al. 2014a, McEachern et al. 2016). Other historical data for Santa Cruz Island are chronicled through a compendium of important books published by the Santa Cruz Island Foundation, including works by Daily (2012), Caire (1990, 1993), Chiles (2011), Eaton (1980), Gherini (2015), Pinney (1994), and Stanton (1984). The Islapedia website (http://www .islapedia.com) and an extensive bibliography of island research (http://santacruz.nrs.ucsb .edu/research/bibliography-publication) are also valuable resources for understanding Santa Cruz and broader Channel Island history.

Although Santa Cruz Island is not as well researched as other islands, a series of studies on Santa Cruz Island paleontology and geology has helped to document the island's broader historical ecology. The other Northern Channel Islands have several studies of island fossil and subfossil sites that are particularly valuable for understanding ancient floral and faunal communities, as well as extinctions and Native American introductions of species (Johnson 1972, Guthrie 1980, 1993, Agenbroad
1998, Jones et al. 2008, Anderson et al. 2010, Rick et al. 2012, Collins et al. 2018). On Santa Cruz Island, a study of Holocene sediments helps chronicle the effects of overgrazing and ranching (Perroy et al. 2012). The remains of mammoths have also been recovered and reported from Santa Cruz Island, although these types of remains are less abundant on Santa Cruz Island than on Santa Rosa and San Miguel Islands (Cushing et al. 1984). Similarly, plant macrofossils from Cañada de los Sauces on Santa Cruz Island help characterize Pleistocene plant communities on the Northern Channel Islands (Chaney and Mason 1930). Analysis of fossil and subfossil animal remains, pollen, phytoliths, and other paleobiological data has great potential on Santa Cruz Island, and future research can help fill important gaps in our understanding of Santa Cruz Island's ecological history.

From these studies and discussions at the island workshop emerged several important questions that can help us determine how to best document past conditions. We outline 4 of these questions that we believe can drive future research: (1) What was the nature of "pristine" Santa Cruz Island ecosystems? (2) How have humans shaped island ecosystems through time? (3) What historical baselines can paleoecological and archaeological records provide to inform restoration and conservation management practices? And (4) what are the broader implications of Santa Cruz Island historical ecology?

To address these questions and build on many of the studies outlined here, we propose the following broad action items: (1) inventory global museum collections from the Channel Islands relevant to island historical ecology and use these to create new questiondriven research projects; (2) create a series of databases that archive legacy data, specimen samples, field notes, oral histories, and publications, including those from archaeological, paleobiological, and historical projects (see Table 1); (3) increase field and other research in archaeology, history, and paleontology, particularly from threatened or vulnerable sites, with research guided by historical ecological questions; (4) expand interdisciplinary research and emerging methodological techniques such as aDNA and stable isotope analysis; and (5) increase collaboration between island partners and with local Chumash communities, 
TABLE 1. Examples of potential Santa Cruz Island historical ecology databases.

\begin{tabular}{|c|c|}
\hline Database type & Description/potential uses \\
\hline Fossil localities (by time period, taxa, etc.) & $\begin{array}{l}\text { Record of biogeography, species distributions, colonization/extinction } \\
\text { events, etc. }\end{array}$ \\
\hline $\begin{array}{l}\text { Archaeological site distribution data (e.g., } \\
\text { Native American, Paleocoastal, cave and } \\
\text { rockshelter, EuroAmerican, Chinese } \\
\text { abalone fishing, etc.) }\end{array}$ & $\begin{array}{l}\text { Confidential databases of cultural sites, with information on location, } \\
\text { time period, size, contents, excavation/collection status, etc. }\end{array}$ \\
\hline Radiocarbon dates for archaeological sites & Master chronology for sites and collections, paleodemography, etc. \\
\hline $\begin{array}{l}\text { Paleobotanical data (macrosopic remains, } \\
\text { charcoal/wood identification, pollen, } \\
\text { phytolith/starch grains, etc.) }\end{array}$ & $\begin{array}{l}\text { Document human use of plants through space and time, ancient } \\
\text { patterns of floral change, fire history, colonization/extinction } \\
\text { events, etc. }\end{array}$ \\
\hline $\begin{array}{l}\text { Zooarchaeological data (mammals, fish, } \\
\text { shellfish, birds, reptiles and amphibians, } \\
\text { insects, extinct fauna, exotic species, etc.) }\end{array}$ & $\begin{array}{l}\text { Document human use of animals, ancient patterns of faunal change, } \\
\text { colonization/translocation/extinction events, etc. }\end{array}$ \\
\hline $\begin{array}{l}\text { Isotopic data (marine shellfish, animal bone } \\
\text { collagen, etc.) }\end{array}$ & $\begin{array}{l}\text { Track variation in nearshore ocean temperatures through space and } \\
\text { time, human residence and migration, human migrations, } \\
\text { subsistence patterns, food web shifts }\end{array}$ \\
\hline $\begin{array}{l}\text { Genetic data (ancient DNA samples, human } \\
\text { and nonhuman) }\end{array}$ & $\begin{array}{l}\text { Document the evolutionary histories of plants and animals, human } \\
\text { evolution and demography, biogeography, human interactions, etc. }\end{array}$ \\
\hline Human health and bioarchaeological data & $\begin{array}{l}\text { Skeletal and other analyses of human remains to document health } \\
\text { indicators and change through time }\end{array}$ \\
\hline Human interaction/exchange databases & $\begin{array}{l}\text { Obsidian sourcing/hydration data, fused shale and soapstone } \\
\text { distribution, deer and other exotic bone distributions to document } \\
\text { trade patterns and the flow of goods and people }\end{array}$ \\
\hline Historic maps and images & $\begin{array}{l}\text { Track landscape change through time, archaeological and historic site } \\
\text { location, etc. Create GIS layers of all data types/disciplines with } \\
\text { GPS locations for interdisciplinary uses }\end{array}$ \\
\hline Ethnohistoric data & $\begin{array}{l}\text { Baptismal and marriage records, death records, and descendant } \\
\text { communities to help recreate past human communities, including } \\
\text { oral histories, writings, photographs, and personal items }\end{array}$ \\
\hline
\end{tabular}

incorporating traditional ecological knowledge into research paradigms. We expand on these areas in the sections that follow.

\section{Documentation of the Present}

The second question from our workshop asked, "How can researchers better document the present?" As scholars of deep history, who primarily consult archaeological and historical data sets, we understand that our efforts to document the past are tied to the documentation of the present. First summarized by geologist Charles Lyell during the nineteenth century Scottish Enlightenment is the idea that the present is the key to understanding the past. On Santa Cruz Island, understanding the past requires thorough documentation of archaeological, geological, and deep historical records, and the processes that continue to shape and reshape these archives of the past. Due in part to its large size and rugged terrain, a large percentage of Santa Cruz Island has never been systematically surveyed for archaeological sites, leaving significant gaps in our geographic documentation of archaeological site locations. For example, there has been no systematic survey of the Santa Cruz Island coastline for cultural resources, as has been accomplished on Anacapa, Santa Rosa, San Miguel, Santa Barbara, San Nicolas, and San Clemente Islands. In an effort to address this gap, for the past 3 years TNC has supported a systematic archaeological survey of the western Santa Cruz Island shoreline (Rick et al. 2014b, Erlandson et al. $2015 \mathrm{~b}, 2016 \mathrm{~b}$ ), including extensive radiocarbon dating that documents both the spatial and temporal distribution of archaeological sites (see Erlandson and Moss 1999, Braje et al. 2005, Erlandson et al. 2017). With the rampant destruction of archaeological sites and other cultural resources by coastal erosion and the growing impacts of anthropogenic climate change on the stability of shell middens and other archaeological features, the comprehensive documentation of these resources is critical for future research and management efforts (Erlandson 2008, Reeder et al. 2012). 


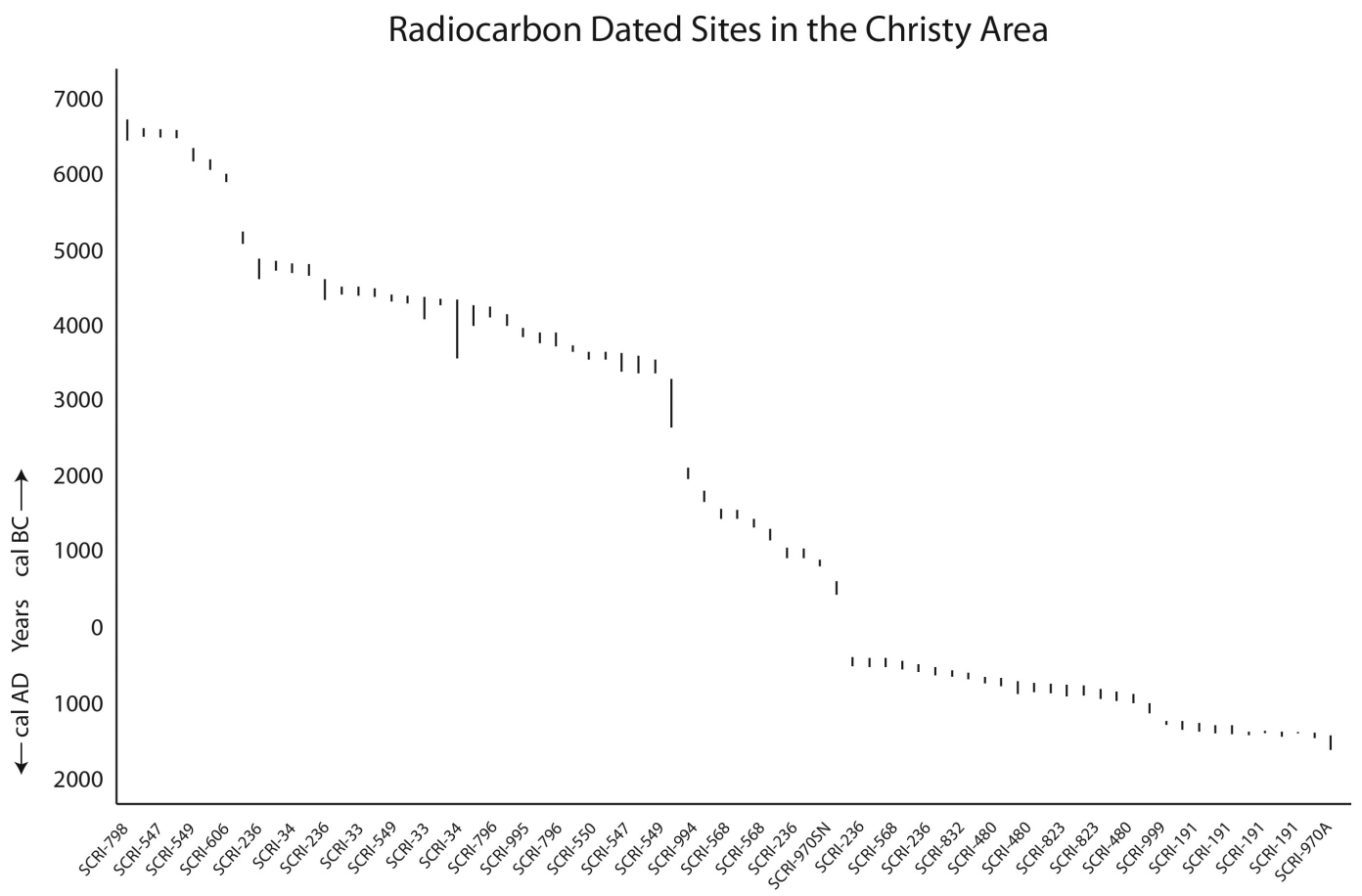

Fig. 1. Radiocarbon dates from archaeological sites in the Christy Drainage of western Santa Cruz Island (from Erlandson et al. 2016b).

In much the same way, existing collections from Santa Cruz Island archaeological resources are limited in their temporal and spatial scope. Robust samples are available from the Historic and Late Holocene periods on Santa Cruz Island, potentially offering the best resolution for these time periods on any of the Channel Islands (see Arnold 2001, Sutton 2014, Thakar 2014). We also have detailed sequences from single sites on the island, such as Punta Arena (CA-SCRI-109) on the southwest coast (Glassow et al. 2008, Gusick 2012), CA-SCRI-333 on the west end (Jazwa et al. 2013), and Diablo Valdez (CA-SCRI-619/620) in the uplands near Diablo Peak on the northern side (Gill 2015). Past research, when combined with recent survey and dating efforts, has compiled long and nearly continuous sequences of human occupation for the Christy, Punta Arena, and Northwest Coast areas (Erlandson et al. 2016b), sequences that are invaluable for understanding the historical ecology of the island (Fig. 1).

What are missing are samples of artifacts and ecofacts from a broader temporal and geographic range of archaeological deposits.
On San Miguel and Santa Rosa, archaeologists over the last 20 years have excavated test pits, column samples, or small bulk samples from a variety of archaeological sites. These efforts have helped to build archival databases of human-environmental ecodynamics through deep time and across island landscapes. Similar research is needed for Santa Cruz Island to understand how humans have altered local ecosystems over millennia and how Santa Cruz Island ecosystems compare to other islands around the world.

In many ways, it is a race against time to build these essential data sets for future generations of archaeologists and historical ecologists. Rising seas, accelerated erosion, and other natural and cultural transformation processes result in the loss of more and more archaeological deposits every year (see Reeder et al. 2012). Additionally, some modern restoration efforts are having impacts on archaeological research and cultural resource management in unanticipated ways. Successful efforts to restore island vegetation communities, for example, help stabilize archaeological sites, but also make archaeological sites more 
difficult to detect during archaeological surveys. Restoration of marine mammal populations also can detrimentally impact archaeological deposits. On San Miguel Island, for example, population pressure at the large pinniped rookery at Point Bennett resulted in a breeding population of California sea lions and elephant seals hauling out and breeding at new beaches or rocky points. Braje et al. (2011) and Rick et al. (2009) documented the catastrophic destruction of a Middle Holocene shell midden and Late Holocene village site in just 12 months, the direct result of marine mammal-created erosion. Protected pinniped populations are also impacting many other archaeological sites on San Miguel, ranging in age from the Early Holocene (Jew et al. 2016) to historical times (Braje et al. 2014).

Better documentation of the present also facilitates our interpretation of the deep past. Reconstructing settlement and mobility on the Channel Islands, for example, requires knowledge about the availability of freshwater, fish and shellfish, edible plants, toolstone sources, asphaltum deposits, and other essential resources for indigenous peoples. While the availability of these resources has fluctuated through time, better understanding the modern state offers a useful baseline to measure against past conditions. For example, contemporary seal and sea lion abundance, or the recovery of geophytes and other plants following pig and other livestock removal, can be compared to past abundance.

The challenges related to documenting the present leave us with a number of important questions to drive future research: (1) What are the geographic and temporal gaps in our understanding of the archaeological record? (2) How are modern natural and cultural taphonomic processes impacting this record? And (3) how are modern ecosystems structured and how can this knowledge be applied to our understanding of the deep past? Addressing these questions will require (1) increased surveys, radiocarbon dating, and sampling of archaeological sites across island landscapes; (2) scientific documentation of the impacts and rates of taphonomic processes, such as coastal and headward erosion; and (3) the formation of interdisciplinary teams to better document present distributions or availabilities of critical resources for ancient subsistence and cultural systems.

\section{Capitalizing ON Collections, Materials, AND Data}

The final question from our workshop was as follows: How can we better capitalize on historical and modern collections to make the most informed conservation decisions? Throughout the development of the disciplines of archaeology, history, and paleobiology, field methods and scientific norms have evolved tremendously. A century ago, for example, archaeologists focused on the largest and "richest" archaeological sites, such as villages and cemeteries. They excavated massive samples, but often collected only select materials such as complete artifacts, whole animal bones and shells, and human remains. Fortunately, times have changed and modern archaeological excavations are now performed with a conservation ethos and a focus on careful recovery and detailed analysis of a wide variety of ecofacts and artifacts. Similar advances have been made in the interpretation of historical documents or the recovery of fossil materials from paleontological sites. Previous archaeological and paleobiological research has resulted in large collections of materials in repositories and museums, especially from archaeological sites. Such is the case for Santa Cruz Island and the other Channel Islands, whose massive collections are housed at the UC Santa Barbara Repository for Archaeological and Ethnographic Collections, the Santa Barbara Museum of Natural History, the Natural History Museum of Los Angeles County, UCLA, the Hearst Museum of Anthropology at UC Berkeley, the Smithsonian National Museum of Natural History, and other institutions. A variety of modern archaeological research has featured these collections, but their vast research potential remains underexploited.

These collections can help us better understand biogeographical shifts, the effects of climate change, and the complex processes of human-environmental ecodynamics over the longue durée. Physical materials in museum holdings can be leveraged into new ideas and information using modern methods and technologies such as applied zooarchaeology, geochemical analyses, and aDNA. These studies offer avenues for new insights into what Channel Island ecosystems once were and what we hope them to be in the future, and these studies provide clear examples of interdisciplinary 
research that integrates archaeology, paleobiology, and history. For example, aDNA studies can test for population bottlenecks, the genetic histories of related animals, and cryptic diversity, as well as better constrain the age and patterns of biological extinctions and introductions to the islands (e.g., Hofman et al. 2015). Applied zooarchaeology can help us unravel the relative abundances and sizes of animals such as fish (e.g., Braje et al. 2012, 2017) and shellfish (Erlandson et al. 2005, 2008) through time. Stable isotopic analyses can help decode the interrelationships between fluctuations in local sea surface temperatures (see Kennett 2005) and shifts in food webs and diets (e.g., Hofman et al. 2016). Better knowledge of such links and patterns in the past can help us develop effective models and management strategies for the rapidly changing world of the future.

There is a similar wealth of historical documents housed in various archives around California and beyond. As noted above, there is already a series of important historical works focused on Santa Cruz and the other Channel Islands, with the Islapedia website making many of these more accessible. Future efforts could review these and other documents through a new lens focused on what they tell us about island ecology and landscape change. The Historic Period was a time of dramatic biological change on the Channel Islands, but the details of these changes need to be better understood. Documenting such processes could help evaluate the full impact of biological changes on island ecosystems and how best to transcend them.

Realizing the potential of historical documents and archaeological and paleontological collections and incorporating them into current and future research can be enhanced by developing a thorough and centrally located database and records management system. Scientists, especially across institutions and disciplines, may be unaware of past or current research projects and the materials stored in museums and other repositories. A central database that lists the research projects, materials recovered, recovery techniques, and storage locations could revolutionize the interdisciplinary and historical ecological potential of future research on the Channel Islands. The National Park Service permitting and reporting system and the UC Santa Barbara RAMS system contain information on many projects that can help kickstart this effort. Part of the challenge will be to develop long-term sample retention plans and destructive-use protocols for emerging technologies. We also need increased digitization of photographs, field notes, artifacts, and other records that can help document past and ongoing research to ultimately help us better prepare for the future. Such databases for the historical sciences could be linked to and paired with similar synthetic databases for island botany, zoology, and other disciplines. A possible analogy for such a data set is the Paleobiology Database (https://paleo biodb.org/\#/), a database used by paleontologists that serves as an archive and a source of data for important research projects. Another model is the Island Digital Ecosystem Avatar (IDEA) databases currently being compiled for the islands of Mo'orea and Crete (https:// mooreaidea.ethz.ch/). Ultimately, such databases for Santa Cruz Island and the other Channel Islands could be woven into current projects, but would need funding to input legacy data. This effort, however, would encourage interdisciplinary synthesis, reward future research, improve management practices, and meet current or emerging ethical standards in many scientific fields.

\section{Concluding Remarks}

The IR initiative is an important interdisciplinary and collaborative effort that has the potential to unite research across disciplinary boundaries and enhance resource conservation, restoration, management, and sustainability on Santa Cruz Island and the other Channel Islands. Challenges still face this effort, but it can facilitate Channel Islands management and research, as well as serve as a model approach for islands and other areas around the world. We have highlighted some of the ways that researchers have already documented the past on Santa Cruz Island, as well as some guiding questions for future work. We also have discussed the need to better document archaeological and paleontological collections, and to continue researching historical archives, with a key future effort being development of a series of large open-access databases and implementation of database management of island research. Syntheses of such "big data" sources are transforming science 
around the world and can do the same for California's Channel Islands. Compiling such databases, as well as marshaling the resources to do so, will be an effort that requires collaboration between a variety of organizations, agencies, and institutions.

A final point touched on at our workshop and one area in great need of enhancement is work with the Chumash and Tongva communities on their perspective of Channel Island management and sustainability. Most of the archaeological record of the Channel Islands that we study to understand the historical ecology of the archipelago is a history created by their ancestors. Incorporating their perspectives can lead to more inclusive, ethical, and comprehensive resource management strategies. Additionally, conversations and a complete oral history project with members of the various ranching families and long-term island researchers could also help us to better understand the past of Santa Cruz Island and establish a path forward for the future.

In looking outside of the confines of our cultural group from the IR workshop, we see our deep historical disciplines as cross-cutting many management areas. These include the 3 other groups from our workshop: marine, faunal, and floral. For instance, a wealth of historical data on island animal communities currently exists and data on island plant communities is growing. These data cross over both marine and terrestrial environments. The key as we move forward in IR and management is integrating these disciplines through increased collaboration and linking the past and present to prepare us for the challenges of the future.

\section{ACKNOWLEDGMENTS}

We thank Scott Morrison, The Nature Conservancy, and all the participants of the 2016 Island Rediscovery workshops. We are also grateful to Mike Glassow, the editors, and anonymous reviewers for help with the review, revision, and publication of this paper.

\section{Literature Cited}

Agenbroad, L.D. 1998. New pygmy mammoth (Mammuthus exilis) localities and radiocarbon dates from San Miguel, Santa Rosa, and Santa Cruz Islands, California. Pages 169-175 in P. Weigand, editor, Contributions to the geology of the Northern Channel Islands, Southern California. Pacific Section of the American Association of Petroleum Geologists, Bakersfield, CA.

Anderson, R.S., S. Starkatt, R.M. Brunner Jass, and N. Pinter. 2010. Fire and vegetation history on Santa Rosa Island, Channel Islands, and long-term environmental change in southern California. Journal of Quaternary Science 25:782-797.

ARNOLD, J.E. 1987. Craft specialization in the prehistoric Channel Islands, California. University of California Publications in Anthropology 18. University of California Press, Berkeley, CA.

ARNOLD, J.E. 1990. An archaeological perspective on the historic settlement pattern on Santa Cruz Island. Journal of California and Great Basin Anthropology 12:112-127.

ARNOLD, J.E. 1991. Transformation of a regional economy: sociopolitical evolution and the production of valuables in southern California. Antiquity 65:953-962.

ARnold, J.E, EDITOR. 2001. The origins of a Pacific Coast chiefdom: the Chumash of the Channel Islands. University of Utah Press, Salt Lake City, UT.

ArNold, J.E., AND L. Martin. 2014. Botanical evidence of paleodietary and environmental change: drought on the Channel Islands, California. American Antiquity $79: 227-248$

BRAje, T.J. 2016. Shellfish for the celestial empire: the rise and fall of commercial abalone fishing in California. University of Utah Press, Salt Lake City, UT.

Braje, T.J., J. Costello, J.M. Erlandson, and R. DeLong. 2014. Of seals, sea lions, and abalone: the archaeology of a historic multi-ethnic basecamp on San Miguel Island, California. Historical Archaeology 48:122-142.

Braje, T.J., J.M. Erlandson, and T.C. Rick. 2005. Reassessing human settlement on the south coast of San Miguel Island, California: the use of ${ }^{14} \mathrm{C}$ dating as a reconnaissance tool. Radiocarbon 47:11-19.

Braje, T.J., T.C. Rick, and J.M. Erlandson. 2012. Rockfish in the longview: applied archaeology and conservation of pacific red snapper (genus Sebastes) in southern California. Pages 157-178 in S. Wolverton and R.L. Lyman, editors, Applied zooarchaeology and conservation biology. University of Arizona Press, Tucson, AZ.

Braje, T.J., T.C. Rick, J.M. Erlandson, M. Anderson, AND R.L. DeLong. 2011. Conflicts in natural and cultural resource management: archaeological site disturbances by seals and sea lions on California's Northern Channel Islands. Journal of Field Archaeology 36:312-321.

Braje, T.J., T.C. Rick, P. Szpak, S.D. Newsome, J.M. McCain, E. Eliott Smith, M. Glassow, and S. Hamilton. 2017. Historical ecology and the conservation of large, hermaphroditic fishes in Pacific Coast kelp forest ecosystems. Science Advances 3(2): e1601759. https:/doi.org/10.1126/sciadv.1601759

Caire, H. 1990. Senor Castillo, cock of Santa Cruz Island. Santa Cruz Island Foundation, Santa Barbara, CA.

CaIre, H. 1993. Santa Cruz Island: a history and recollection of an old California rancho. Arthur H. Clark Publishers, Spokane, WA.

Chaney, R.H., And H.L. Mason. 1930. A Pleistocene flora from Santa Cruz Island, California. Carnegie Institution of Washington Publication 415:1-24.

Chiles, F.C. 2011. Justin Caire and Santa Cruz Island: the rise and fall of a California dynasty. Arthur $\mathrm{H}$. Clark Company, Spokane, WA.

Collins, P.W., D.A. Guthrie, E.L. Whistler, R.L. VelLanoweth, and J.M. Erlandson. 2018. Terminal 
Pleistocene-Holocene avifauna of San Miguel and Santa Rosa islands: identification of previously unidentified avian remains recovered from fossil sites and prehistoric cave deposits. Western North American Naturalist 78(4). https://scholarsarchive.byu .edu/wnan/vol78/iss4/35

Colten, R.H. 1993. Prehistoric subsistence, specialization, and economy in a southern California chiefdom. Doctoral dissertation, University of California, Los Angeles.

Colten, R.H. 2001. Ecological and economic analysis of faunal remains from Santa Cruz Island. Pages 199-219 in J.E. Arnold, editor, The origins of a Pacific Coast chiefdom: the Chumash of the Channel Islands. University of Utah Press, Salt Lake City, UT.

Colten, R.H., AND J.E. ARNOLD. 1998. Prehistoric marine mammal hunting on California's Northern Channel Islands. American Antiquity 63:679-701.

Cushing, J., M. Daily, E. Noble, V.L. Roth, and A. WenNER. 1984. Fossil mammoths from Santa Cruz Island, California. Quaternary Research 21:376-384.

Daily, M. 2012. The California Channel Islands. Arcadia Publishing, Charleston, SC.

Eaton, M.A. 1980. Diary of a sea captain's wife: tales of Santa Cruz Island. McNally and Loftin, Santa Barbara, CA.

ERLANDSON, J.M. 2008. Racing a rising tide: global warming, rising seas, and erosion of human history. Journal of Island and Coastal Archaeology 3:167-169.

Erlandson, J.M. 2016. Coastal versus interior: some thoughts on the archaeology of California's Channel Islands. Journal of Island and Coastal Archaeology 11:443-446.

Erlandson, J.M., K.M. Gill, T.J. Braje, and A.E. Gusick. 2016b. As the world warms: rising seas, coastal erosion, archaeology, and historical ecology on Santa Cruz Island. Report submitted to The Nature Conservancy, San Francisco, CA.

Erlandson J.M., K.M. Gill, M.A. Glassow, and A.E. Gusick. 2016a. Three Paleocoastal lithic sites on Santa Cruz Island, California. PaleoAmerica 2:52-55.

Erlandson, J.M., K.M. Gill, A.E. Gusick, and A.E. DORRLER. 2017. Identifying shell middens with historic aerial photos: an example from California's Santa Cruz Island. Journal of Island and Coastal Archaeology. https://doi.org/10.1080/15564894.2017 .1324926

Erlandson, J.M., K.M. Gill, T.C. Rick, and T.J. Braje. 2015b. Racing the rising tide: coastal erosion, archaeology, and historical ecology on western Santa Cruz Island. Report submitted to The Nature Conservancy, San Francisco, CA.

Erlandson, J.M., K.M. Gill, T.C. Rick, and L. ReEderMyers. 2015a. Three Paleocoastal shell middens on Santa Cruz Island, California. PaleoAmerica 1: $113-115$.

ErLandson, J.M., AND M.L. Moss. 1999. The systematic use of radiocarbon dating in archaeological surveys in coastal and other erosional environments. American Antiquity 64:431-443.

Erlandson, J.M., T.C. Rick, T.J. Braje, M. Casperson, B. Culleton, B. Fulfrost, T. Garcia, D.A. Guthrie, N. Jew, and D.J. Kennett, et aL. 2011. Paleoindian seafaring, maritime technologies, and coastal foraging on California's Channel Islands. Science 331: $1181-1185$.

Erlandson, J.M., T.C. Rick, T.J. Braje, A. Steinberg, and R.L. Vellanoweth. 2008. Human impacts on ancient shellfish: a 10,000 year record from San Miguel Island, California. Journal of Archaeological Science 35:2144-2152.

Erlandson, J.M., T.C. Rick, J.A. Estes, M.H. Graham, T.J. Braje, and R.L. Vellanoweth. 2005. Sea otters, shellfish, and humans: 10,000 years of ecological interaction on San Miguel Island, California. Pages 9-21 in D. Garcelon and C. Schwemm, editors, Proceedings of the Sixth California Islands Symposium. National Park Service Technical Publication CHIS05-01. Institute for Wildlife Studies, Arcata, CA.

Fischer, D.T., C.J. Still, and A.P. Williams. 2009. Significance of summer fog and overcast for drought stress and ecological functioning of coastal California endemic plant species. Journal of Biogeography 36:783-799.

GherinI, J. 2015. Santa Cruz Island: a history of conflict and diversity. University of Oklahoma Press, Norman, $\mathrm{OK}$.

GILL, K.M. 2013. Paleoethnobotanical investigations on the Channel Islands: current directions and theoretical considerations. Pages 113-136 in C. Jazwa and J. Perry, editors, California's Channel Islands: the archaeology of human-environment interactions. University of Utah Press, Salt Lake City, UT.

GILL, K.M. 2014. Seasons of change: using seasonal morphological changes in Brodiaea corms to determine season of harvest from archaeobotanical remains. American Antiquity 79:638-654.

GILL, K.M. 2015. Ancient plant use and the importance of geophytes among the island Chumash of Santa Cruz Island, California. Doctoral dissertation, Department of Anthropology, University of California, Santa Barbara.

GILL, K.M. 2016. 10,000 years of geophyte use among the island Chumash of the Northern Channel Islands. Fremontia 44(3):34-38.

GiLL, K.M., AND K.M. Hoppa. 2016. Evidence for an island Chumash geophyte-based subsistence economy on the Northern Channel Islands. Journal of California and Great Basin Anthropology 36:51-71.

GLassow, M.A. 1993a. The occurrence of red abalone shells in Northern Channel Island archaeological middens. Pages 567-576 in F.G. Hochberg, editor, Third California Islands Symposium: recent advances in research on the California Islands. Santa Barbara Museum of Natural History, Santa Barbara, CA.

GLAsSOW, M.A. 1993b. Changes in subsistence on marine resources through 7,000 years of prehistory on Santa Cruz Island. Pages 75-94 in M.A. Glassow, editor, Archaeology of the Northern Channel Islands of California: studies of subsistence, economics, and social organization. Coyote Press, Salinas, CA.

GLassow, M.A. 2013. Settlement systems on Santa Cruz Island between 6300 and 5300 BP. Pages 60-74 in J.E. Perry and C. Jazwa, editors, California's Channel Islands: the archaeology of human-environment interactions. University of Utah Press, Salt Lake City, UT.

GLassow, M.A. 2015. Red abalone middens on Santa Cruz Island, California: chronology and evidence of emergent complexity. American Antiquity 80:745-759.

Glassow, M.A., J.E. Perry, and P.F. Paige. 2008. The Punta Arena site: Early and Middle Holocene cultural development on Santa Cruz Islands. Contributions to Anthropology 3. Santa Barbara Museum of Natural History, Santa Barbara, CA. 
Gusick, A.E. 2012. Behavioral adaptations and mobility of Early Holocene hunter-gatherers, Santa Cruz Island, California. Doctoral dissertation, University of California, Santa Barbara.

Gusick, A.E. 2013. The Early Holocene occupation of Santa Cruz Island. Pages 40-59 in J.E. Perry and C. Jazwa, editors, California's Channel Islands: the archaeology of human-environment interactions. University of Utah Press, Salt Lake City, UT.

Gusick, A.E., M.A. Glassow, and P. Paige. 2016. Fish remains as indicators of changes in environment, technology, and sociopolitical organization on Santa Cruz Island. Journal of California and Great Basin Anthropology 35:217-235.

Guthrie, D.A. 1980. Analysis of avifaunal and bat remains from midden sites on San Miguel Island. Pages 689-702 in D. Power, editor, The California Islands: Proceedings of a Multidisciplinary Symposium. Santa Barbara Museum of Natural History, Santa Barbara, CA.

Guthrie, D.A. 1993. New information on the prehistoric fauna of San Miguel Island, California. Pages 405-416 in F.G. Hochberg, editor, Third California Islands Symposium: recent advances in research on the California Islands. Santa Barbara Museum of Natural History, Santa Barbara, CA.

Hofman, C., T.C. Rick, M. Hawkins, W.C. Funk, K. Ralls, C. Boser, P.W. Collins, T. CoOnan, J.L. King, and S.A. Morrison, ET AL. 2015. Mitochondrial genomes suggest rapid evolution of dwarf California Channel Islands foxes (Urocyon littoralis). PLOS ONE 10(2):e0118240. https://doi.org/10.1371/journal.pone .0118240

Hofman, C., T.C. Rick, J.E. Maldonado, P.W. Collins, J.M. Erlandson, R. Fleischer, K. Ralls, C. Smith, W. Teeter, R. Vellanoweth, and S.D. Newsome. 2016. Tracking the diet of an island carnivore (Urocyon littoralis) across 7300 years of human cultural and environmental change. Quaternary Science Reviews 146:147-160.

Hoover, R.L. 1971. Some aspects of Santa Barbara Channel prehistory. Doctoral dissertation, University of California, Berkeley.

Hoppa, K.M. 2014. Terrestrial resource exploitation on Santa Cruz Island, California: macrobotanical data from four Middle Holocene sites. Monographs of the Western North American Naturalist 7:109-117.

JaCkson, J.B.C., M.X. Kirby, W.H. Berger, K.A. BJornDaL, L.W. BotsFord, B.J. Bourque, R.H. Bradbury, R. Cooke, J. Erlandson, J.A. Estes, et al. 2001. Historical overfishing and the recent collapse of coastal ecosystems. Science 293:629-637.

Jazwa, C.S., L.H. Gamble, and D.J. Kennett. 2013. A high-precision chronology for two house features at an early village site on western Santa Cruz Island, California, USA. Radiocarbon 55(1):185-199.

JazWa, C.S., AND J.E. Perry. 2013. The ecological, environmental, and cultural contexts for island archaeology. Pages 5-25 in C. Jazwa and J. Perry, editors, California's Channel Islands: the archaeology of human-environment interactions. University of Utah Press, Salt Lake City, UT.

Jew, N.P., T.J. Braje, and J.M. Erlandson. 2016. Pinnipeds and paleocoastal middens near Point Bennett, San Miguel Island. Journal of Island and Coastal Archaeology. https://doi.org/10.1080/15564894.2015 .1096870
Jew, N.P., T.C. Rick, M.A. Glassow, And J. ARnOlD. 2015. Bayesian ${ }^{14} \mathrm{C}$ analysis, formation processes, and accumulation rates of the Prisoners Harbor Shell Midden and Village Complex, Santa Cruz Island, California. Journal of Archaeological Science: Reports 3:257-264.

Johnson, D.L. 1972. Landscape evolution on San Miguel Island, California. Doctoral dissertation, University of Kansas, Lawrence, KS.

Johnson, J.R., And S. McLendon. 1999. The nature of Chumash sociopolitical groups. Pages 51-66 in S. McLendon and J. Johnson, editors, Cultural affiliation and lineal descent of Chumash peoples in the Channel Islands and Santa Monica Mountains. Report on file at the Archaeology and Ethnography Program, National Park Service, Washington, DC.

Jones, T.L., J.F. Porcasi, J.M. Erlandson, H. Dallas Jr., T.A. WAKE, AND R. SCHWADERER. 2008. The protracted Holocene extinction of California's flightless sea duck (Chendytes lawi) and its implications for the Pleistocene overkill hypothesis. Proceedings of the National Academy of Sciences USA 105:4105-4108.

Junak, S., T. Ayers, R. Scott, D. Wilen, and D. Young. 1995. A flora of Santa Cruz Island. Santa Barbara Botanic Garden, Santa Barbara, CA.

Kennett, D.J. 2005. The island Chumash: behavioral ecology of a maritime society. University of California Press, Berkeley, CA.

LaDochy, S., AND M. Witiw. 2012. The continued reduction in dense fog in the southern California region: possible causes. Pure and Applied Geophysics 169: $1157-1163$.

LIVINGSTON, D.S. 2006. Ranches in the sea: a history of the islands within Channel Islands National Park. Department of the Interior, National Park Service, Channel Islands National Park, CA.

Livingston, D.S. 2016. Island legacies: a history of the islands within Channel Islands National Park, Volume II, Section 4 - Santa Cruz Island. Historic Resource Study, Department of the Interior, Channel Islands National Park, Ventura, CA

Martin, S.L., AND V.S. Popper. 2001. Paleobotanical investigations of archaeological sites on Santa Cruz Island. Pages 245-259 in J.E. Arnold, editor, The origins of a Pacific Coast chiefdom: the Chumash of the Channel Islands. University of Utah Press, Salt Lake City, UT.

McEachern, K., T. Atwater, P.W. Collins, K. Faulkner, AND D.V. Richards. 2016. Managed island ecosystems. Pages 755-778 in H. Mooney and E. Zavaleta, editors, Ecosystems of California. University of California Press, Berkeley, CA.

Morrison, S.A., T.S. Sillett, W.C. Funk, C.K. GhalamBOR, AND T.C. RICK. 2018. California Island rediscovery: building an archive to improve conservation today and equip the historical ecologist of tomorrow. Western North American Naturalist 78(4). https:// scholarsarchive.byu.edu/wnan/vol78/iss $4 / 42$

NOAH, A. 2004. Household economies: the role of animals in a historic period chiefdom on the California coast. Doctoral dissertation, University of California, Los Angeles, CA.

OLSON, R.L. 1930. Chumash prehistory. University of California Publications in American Archaeology and Ethnology 28:1-21.

Pauly, D. 1995. Anecdotes and the shifting baselines syndrome of fisheries. Trends in Ecology and Evolution 10:430. 
Perroy, R.L., B. Bookhagen, O.A. Chadwick, and J.T. HowaRTH. 2012. Holocene and Anthropocene landscape change: arroyo formation on Santa Cruz Island, California. Annals of the Association of American Geographers 102:1229-1250.

Perry, J.E. 2003. Changes in prehistoric land and resource use among complex hunter-gatherer-fishers on eastern Santa Cruz Island, California. Doctoral dissertation, University of California, Santa Barbara.

Perry, J.E. 2004. Quarries and microblades: trends in prehistoric land and resource use on Santa Cruz Island. Pages 113-132 in J.E. Arnold, editor, Foundations of Chumash complexity. Cotsen Institute of Archaeology, University of California, Los Angeles.

Perry, J.E. 2005. Early Period resource use on eastern Santa Cruz Island. Pages 43-53 in D. Garcelon and C. Schwemm, editors, Proceedings of the Sixth California Islands Symposium. National Park Service Technical Publication CHIS-05-01, Institute for Wildlife Studies, Arcata, CA

Perry, J.E., and M.A. Glassow. 2015. Prehistoric settlement in island interiors: evidence from California's Santa Cruz Island. Journal of Island and Coastal Archaeology 10:184-206.

Perry, J.E., and M.A. Glassow. 2016. Response to "Coastal versus interior: some thoughts on the archaeology of California's Channel Islands." Journal of Island and Coastal Archaeology 11:447-449.

PERry, J.E., AND K.M. Hoppa. 2012. Subtidal shellfish exploitation on the California Channel Islands: wavy top (Lithopoma undosum) in the Middle Holocene. Pages 65-86 in M.A. Glassow and T.L. Joslin, editors, Exploring methods of faunal analysis. Cotsen Institute of Archaeology, University of California Los Angeles.

Pinney, T. 1994. The wine of Santa Cruz Island. Santa Cruz Island Foundation, Santa Barbara, CA.

ReEder, L.A., T.C. Rick, AND J.M. ERLANDSON. 2012. Our disappearing past: a GIS analysis of the vulnerability of coastal archaeological resources in California's Santa Barbara Channel region. Journal of Coastal Conservation 16:187-197.

Rick, T.C., J.M. ERLandson, T.J. Braje, and R.L. DeLong, 2009. Seals, sea lions, and the erosion of archaeological sites on California's Channel Islands. Journal of Island and Coastal Archaeology 4:125-131.

Rick, T.C., J.M. Erlandson, K. Gill, L. Reeder-Myers, AND T. BRAJE. 2014b. Rapid archaeological assessment on Santa Cruz Island: GIS modeling, sea level rise, and archaeological survey. Report submitted to The Nature Conservancy, San Francisco, CA.

Rick, T.C., C.A. Hofman, T.J. Braje, J.E. Maldonado, T.S. Sillett, K. Danchisko, and J.M. Erlandson. 2012. Flightless ducks, giant mice, and pygmy mammoths: Late Quaternary extinctions on California's Channel Islands. World Archaeology 44:3-20.

Rick, T.C., T.S. Sillett, C.K. Ghalambor, C.A. Hofman, K. Ralls, R.S. Anderson, C. Boser, T.J. Braje, D. Cayan, and T. Chesser, ET al. 2014a. Ecological change on California's Channel Islands from the Pleistocene to the Anthropocene. BioScience 64: 680-692.

Rogers, D.B. 1929. Prehistoric man on the Santa Barbara coast. Santa Barbara Museum of Natural History, Santa Barbara, CA.

Schoenherr, A.A., C.R. Feldmeth, and M.J. Emerson. 1999. Natural history of the islands of California. University of California Press, Berkeley, CA.

Stanton, C. 1984. An island memoir. Santa Cruz Island Company, Los Angeles, CA.

SutTon, E.A. 2014. Household and community organization at Nimatlala, an island Chumash Village on Limuw (Santa Cruz Island), California. Doctoral dissertation, University of California, Santa Barbara.

ThakaR, H.B. 2012. Ancient actions predict modern consequences: lessons from prehistoric shellfish intensification. Pages 92-109 in S. Wolverton and L. Lyman, editors, Time, space, and form in biological conservation. University of Arizona Press, Tuscon, AZ.

THAKAR, H.B. 2014. Sites forlorn: dating intervals of abandonment at three shell middens on Santa Cruz Island, California using Bayesian chronological models. Journal of Archaeological Science 52:633-634.

THAKar, H.B. 2016. Foraging ancient landscapes: seasonal and spatial variation in prehistoric exploitation of plant and animal food resources on Santa Cruz Island, California. Journal of California and Great Basin Archaeology 36:27-50

Witiw, M.R., AND S. LaDochy. 2008. Trends in fog frequencies in the Los Angeles Basin. Atmospheric Research 87:293-300.

Received 30 January 2017

Revised 7 July 2017

Accepted 16 August 2017

Published online 24 January 2018 